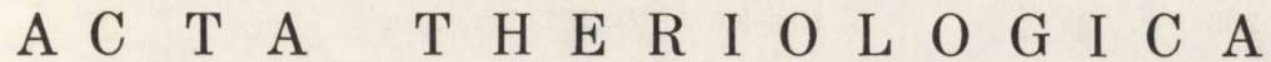

\author{
Krystyna KISIELEWSKA \& Zofia Z UBCZEW KA
}

\section{Intestinal Helminths as Indexes of Reproduction Dynamics in the Host Population - Common Vole*}

\author{
[With 4 Tables \& 4 Figs.]
}

\begin{abstract}
A total of 612 parasitological dissections were made in different seasons in two populations of Microtus arvalis ( $\mathrm{Pa} 11 \mathrm{a} \mathrm{s}, 1779)$ confined in 1-hectare enclosures. The intestinal helminths dominating in the parasitocenosis of voles (Heligmosomum sp. and Syphacia obvelata) are considered to be indexes of the age structure of the host population. The four age classes distinguished for these voles differed in respect of both quantity and quality of invasion. Parasitological data were compared with the voles' age, defined on the basis of eye lens weight. Using parasitological indexes as a basis a description is given of the reproduction dynamics in the vole populations examined. Reproduction was very intensive in 1970 , with a distinct peak during the period from July to September. The percentage of young voles in the population exceeded that of adults. The dominating nematode was Syphacia obvelata. The following year reproduction was less intensive and the percentage of young voles was no longer greater than that of adults. The dominating helminths were representatives of the genus Heligmosomum. Comparison of parasitological data with indirect information on reproduction dynamics of the study populations (percentage of individuals entering the populations) showed that there was considerable agreement between them. The reliability and usefulness of parasitological indexes for estimating the age structure of host populations are discussed.
\end{abstract}

\section{INTRODUCTION}

In the previous study on Microtus arvalis ( $\mathrm{P}$ a 11 a s, 1779) it was shown that there is a relation between the age structure of a population of this rodent and the qualitative and quantitative structure of its parasitocenosis (K is ielew ska, 1971). The author chose species from among the vole's intestinal helminths which could serve as indexes of the age structure of the host population. These are nematodes of the genus Heligmosomum

* Badania były prowadzone w ramach problemu węzłowego 09.1.7., koordynowanego przez Instytut Ekologii PAN.

Acta theriol. 16 
spp. characteristic of adult voles, and the nematode Syphacia obvelata

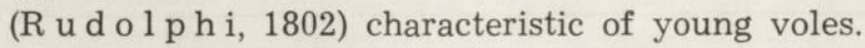

The above regularities were established on the basis of data for young voles caught three times a year (May, July, October) in a lucerne field several hectares in area ( $\mathrm{K}$ is i e le w s k a, 1971). The only criterion then available - body weight and length - was used to estimate the voles' age at that time.

Now that more accurate estimates of voles' age are possible, using the dry eye lens weight as criterion ( $M$ a r t i n e t, 1966), we decided to check the correctness of the regularities observed by Kisielew ska (1971) on the same species of host, but in an isolated population kept under constant ecological and parasitological inspection. Parasitological indexes were used to describe the reproduction dynamics of the study population of voles.

Table 1

Numbers of common voles dissected.

\begin{tabular}{lcr}
\hline \multirow{2}{*}{ Month } & \multicolumn{2}{c}{ No. of voles } \\
\cline { 2 - 3 } & 1970 & 1971 \\
\hline Jan. - Febr. & - & 22 \\
March & - & 10 \\
April & 13 & 79 \\
May & - & 10 \\
June & - & 60 \\
July & 16 & 36 \\
August & 16 & 141 \\
September & - & 47 \\
October & 73 & 30 \\
November & 7 & 47 \\
December & - & 7 \\
\hline Total & 130 & 482 \\
\hline
\end{tabular}

Table 2

Quantitative and qualitative structure of helminthocenosis occurring in the study population of voles.

Species Infestation

\begin{tabular}{lr} 
Heligmosomum spp. & 74 \\
Syphacia obvelata & 35 \\
Trichocephalus muris & 2 \\
Aprostatandrya & \\
macrocephala & 14 \\
Catenotaenia pusilla & 3 \\
\hline
\end{tabular}

II. MATERIAL AND METHODS

The data contained in the present study refer to material accumulated during the period from April 1970 to November 1971 in the experimental fields of the Institute of Ecology, Polish Academy of Sciences, at Dziekanów Leśny near Warsaw. Two 1-hectare lucerne fields were enclosed by an impenetrable fence and wooden hauses containing livetraps placed in them near the various vole colonies (determined on the basis of groups of burrows). The animals were caught using the CMR method (Catch-Mark-Release) for two days (morning and evening) each week throughout the year.

Only those voles which died in traps during captures were used for parasitological dissection in 1970. As from June $19715 \%$ of the current 
population numbers were trapped once a month, and a total of 612 individuals used for parasitological dissection (Table 1). We also knew how many young individuals entered the population each month and also population numbers, these parameters being determined by the Calendar of Captures method (Petrusewicz \& Andrzejewski, 1962). Data on the voles' age were obtained from the dry eye lens weights elaborated by Adamczewska-Andrzejewska (in press).

\section{RESULTS}

\section{Species Composition of the Parasitocenosis in Voles}

The following species of intestinal helminths were found in the study population of voles:

Cestoda: Catenotaenia pusilla (G o e z e, 1782) and Aprostatandrya macrocephala (D e uthill, 1915).

Nematoda: Heligmosomum costellatum (D u j a r d i n, 1845), Heligmosomum polygyrum (D u jar d in, 1845), Syphacia obvelata (R udolphi, 1802), Trichocephalus muris ( $\mathrm{Schrank}, 1788$ ), Tab. 2.

The species composition of the parasitocenosis in an isolated vole population is identical to that in natural population ( $\mathrm{K}$ isielewska, 1971), which is a circumstance greatly fascilitating comparative analysis. On this account only those species which were earlier chosen as indexes of the age structure of vole populations, i.e. nematodes of the genus $\mathrm{He}$ ligmosomum nad the nematode Syphacia obvelata, were taken into consideration in further discussions.

\section{Age Classes in a Population of $M$. arvalis Distinguished on the Basis of Parasitological Indexes}

The relation was traced between extensiveness and intensiveness of infestation in voles by means of indicator helminths and the host's age. The results obtained (Fig. 1,2) confirm Kisielew ska's data (1971) that there is a relation between the voles' age and the quantity and quality of invasion, and that the nematode $S$. obvelata dominates (intensively and extensively) in young voles, and Heligmosomum spp. in older individuals.

The following groups of voles were distinguished on the basis of the quantitative and qualitative structure of invasion (Fig. 1): (a) not invaded, (b) invaded by $S$. obvelata only, (c) invaded simultaneously by $S$. obvelata and Heligmosomum spp., (d) invaded by Heligmosomum spp. only. Each of these groups dominates in a different age class of voles (Table 3 ), as 


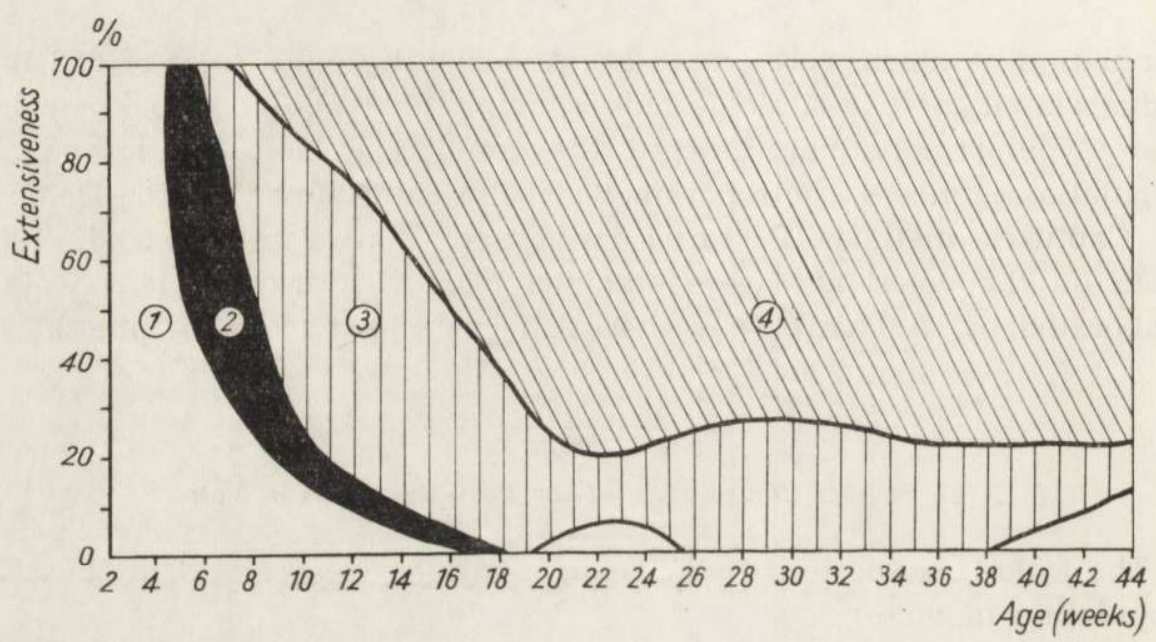

Fig. 1. Extensiveness of invasion of voles by indicator species of nematodes depending on the animals' age.

1 - uninvaded individuals, 2 - individuals invaded by $S$. obvelata, 3 - individuals invaded by $S$. obvelata and Heligmosomum spp., 4 - individuals invaded by Heligmosomum spp.

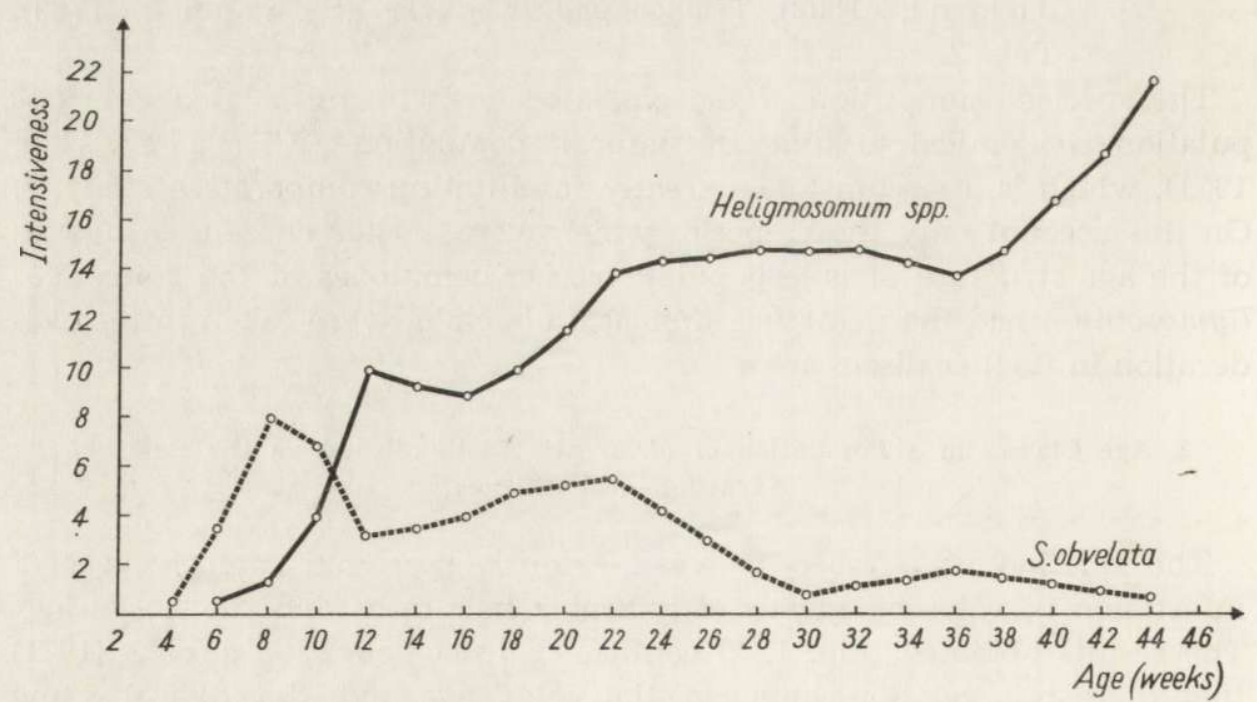

Fig. 2. Intensiveness of invasion of voles by indicator species of nematodes depending on the animals' age.

1 - intensiveness of invasion by $S$. obvelata, $2-$ intensiveness of invasion by $S$. obvelata and Heligmosomum spp.

follows: very young voles are generally free of intestinal helminths. In the subsequent age classes the percentage of uninvaded individuals gradually decreases, becoming practically non-existent in the old class. In young voles, in addition to uninvaded individuals $(40 \%)$, animals invaded 
by $S$. obvelata only decidedly predominate $(43 \%)$. In adult voles (usually sexually active) mixed invasion predominates $\left(57^{0} \%\right)$. In old voles it is mainly individuals invaded by Heligmosomum spp. which are encountered $(76 \%)$. In addition average intensiveness of invasion by $S$. obvelata decreases in successive classes, while invasion by Heligmosomum spp. increases (Fig. 2).

Analysis was also made of the relation between the host's age and number of helminth species occurring in single host individuals (Table 4), taking into consideration here all species included in the composition of the parasitocenosis present in the study population of voles (cf. Table 2). In general it may be said that the qualitative invasion of a host increases

Table 3

Parasitological description of different age classes of $M$. arvalis.

\begin{tabular}{|c|c|c|c|c|c|c|c|c|}
\hline \multirow[t]{2}{*}{ Age group } & \multirow[t]{2}{*}{$\begin{array}{c}\text { Lens weight } \\
\text { (mg) }\end{array}$} & \multirow[t]{2}{*}{ A ge (weeks) } & \multicolumn{4}{|c|}{$\begin{array}{c}\text { Percentage of voles } \\
\text { infested }\end{array}$} & \multicolumn{2}{|c|}{$\begin{array}{l}\text { Intensi- } \\
\text { veness }\end{array}$} \\
\hline & & & Un. & S.o. & $\begin{array}{l}\text { H. }+ \\
\text { S.o. }\end{array}$ & & S.C & H. \\
\hline Very young & $1.2-1.5$ & 4 & 100 & - & - & - & - & - \\
\hline Young & $1.6-2.5$ & $4-8$ & 40 & 43 & 12 & 5 & 5 & 0.1 \\
\hline Adult & $2.6-3.8$ & $8-16$ & 5 & 8 & 57 & 30 & 7.8 & 2.4 \\
\hline Old & $>3.8$ & $>16$ & 2 & 2 & 20 & 76 & 3.1 & 7.0 \\
\hline
\end{tabular}

* Un. - uninfested, S.o. - S. obvelata, H. - Heligmosomum spp.

Table 4

Numbers of parasite species in different age classes of $M$. arvalis.

\begin{tabular}{lrrrr}
\hline \multirow{2}{*}{ Age group } & \multicolumn{4}{c}{ Percentage of individuals invaded by: } \\
\cline { 2 - 3 } & 1 species & 2 species & 3 species & 4 species \\
\hline Very young & - & - & - & - \\
Young & 55 & 5 & - & - \\
Adult & 38 & 37 & 16 & 4 \\
Old & 35 & 47 & 14 & 2 \\
\hline
\end{tabular}

with the latter's age (that is, invasion by more than one species is more often encountered in old individuals). The results obtained, however, are not sufficiently characteristic to be able to distinguish one age class from another on these grounds.

Calculation was made for each of the above age classes, using the t Student test to check significance, of the average eye lens weight and standard deviation (Fig. 3). No statistically significant differences was found between the average eye lens weight in the very young and young classes (Fig. 3), and consequently these two classes were combined. After 
making this change the differences between average dry eye lens weights in the combined class (5) and the other classes are statistically significant.

\section{Reproduction Dynamics in an Isolated Population of $M$. arvalis in Relation to Parasitological Data}

Variations in intensity of invasion by indicator helminths ( $S$. obvelata and Heligmosomum spp. were traced in consecutive months of the study period (Fig. 4), and also the percentage of groups of voles differing in respect of the type of invasion characteristic of the given age classes (Fig. 4B). It was assumed in the light of the discussion given in the preceding section, that increase in the number of uninfested voles and voles infested by $S$. obvelata only, may be taken as indicating that very young and young individuals are present in the given population (Fig. 4B,

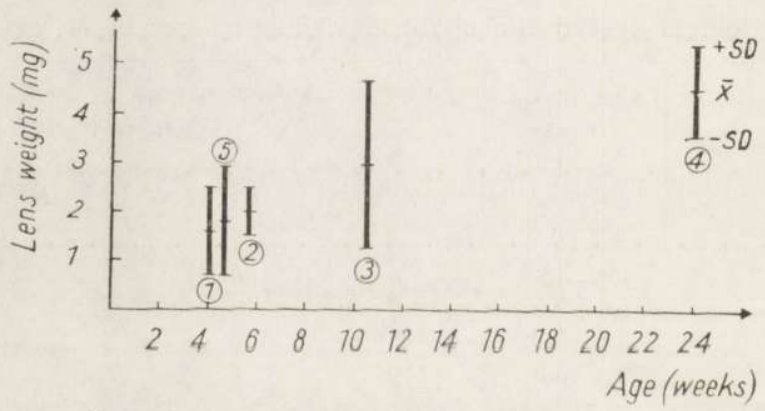

Fig. 3. Averages $\bar{X}$ and standard deviation $S D$ of lens weight in $M$. arvalis of different age groups.

1 - very young, 2 - young, 3 - adult, 4 - old, 5 - very young + young.

July-October 1970 and April-September 1971). The percentage of these young animals in relation to the older groups (invaded by a mixture of parasites, or by Heligmosomum spp. only) can be taken as a measure of reproduction intensity in the population. The decided domination of the type characteristic of adult and old voles (Fig. 4B, November 1970 February 1971) shows that the population is growing older as a result of earlier inhibition of reproduction.

The above assumptions were used to describe the reproduction dynamics of a vole population in two successive reproduction seasons (1970 and 1971):

1. In 1970 reproduction was very intensive, with a distinct peak during the period from July to September. The percentage of young animals in the population exceeds the number of adult individuals during this period. The dominating parasite in the vole population was Syphacia obvelata.

2 . In 1971 the course taken by reproduction was more even (without a distinct peak) and the small increases in the number of young animals did not result in their dominating over the older part of the population. 


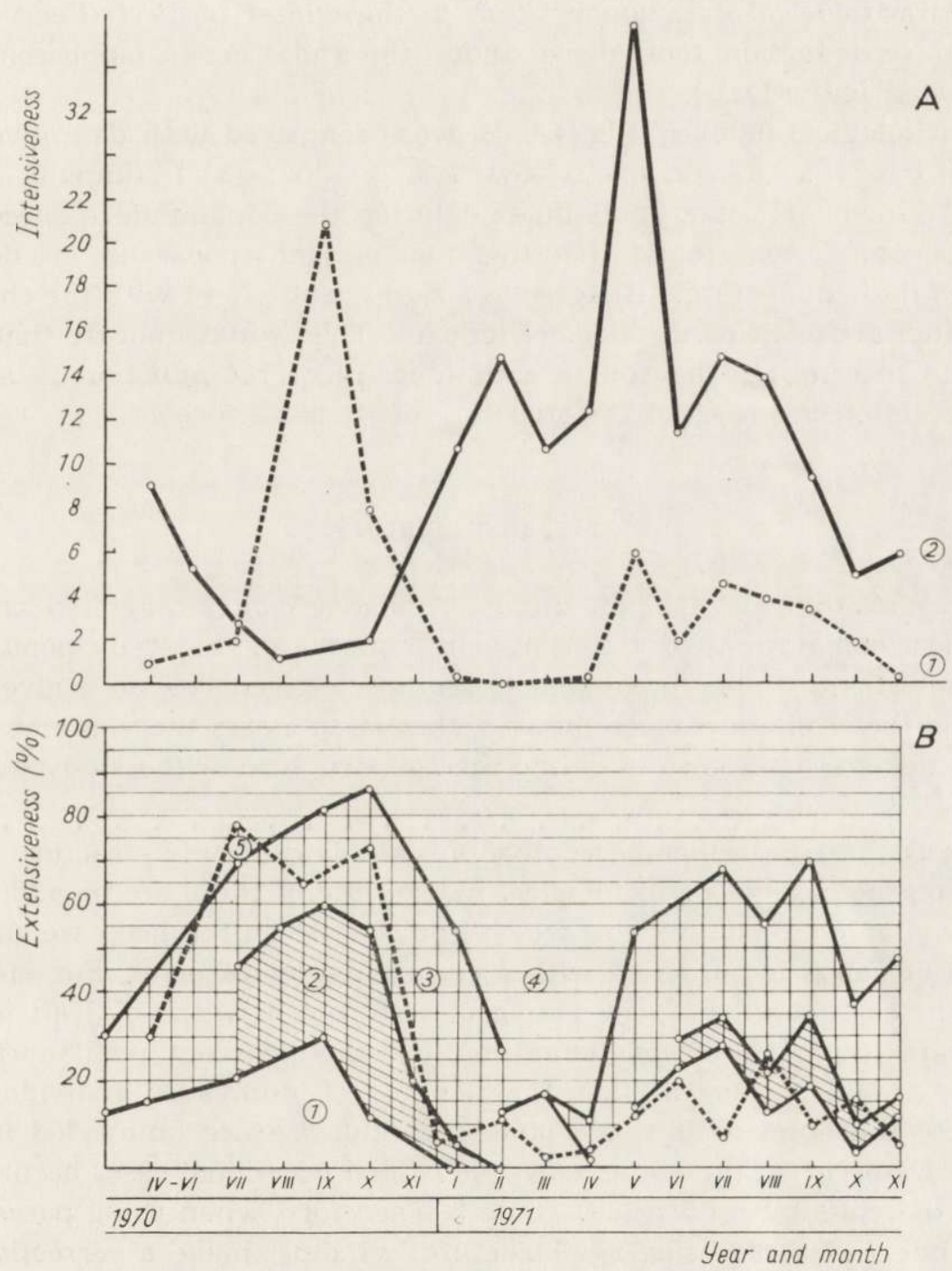

Fig. 4. Dynamics of invasion of population of $M$. arvalis by indicator species of nematodes in 1970 and 1971.

A - intensiveness of invasion: 1 - intensiveness of invasion by $S$. obvelata, $2-$ intensiveness of invasion by Heligmosomum spp. $B$ - extensiveness of invasion: 1 - uninvaded individuals, 2 - individuals invaded by $S$. obvelata, 3 - individuals invaded by $\mathrm{S}$. obvelata and Heligmosomum spp., 4 - individuals invaded by $\mathrm{He}$ ligmosomum spp., $-5-\%$ of individuals entering the population. 
During this reproduction season the helminths dominating in the vole population were nematodes of the genus Heligmosomum.

3. Parasitological data suggest that in the winter of 1971 (FebruaryMarch) reproduction took place under the snow cover (appearance of uninfested individuals).

Parasitological indexes (Fig. 4A, B) were compared with data given by Adamczewska-Andrzejewska \& Jurgiel (unpubl. data) on the number of young individuals entering the population in successive months, and it was found that the dynamics of appearance of newlymarked individuals (Fig. 4B) agree to a significant extent with the changes presented above in parasitological indexes. This would indicate that it is possible to estimate the course and intensity of reproduction in a vole population on the basis of the structure of its parasitocenosis.

\section{DISCUSSION}

The parasitological indexes discussed above can be applied only to statistical elaborations of material representative of the study population of the host, since it is impossible to allocate a given vole to a given age class on the strength of such indexes, that is, to assess the vole's absolute age in this way, but only to define the age structure of the study population.

It must also be remembered that an estimate of this structure made solely on the basis of parasitological indexes (i.e. if there are no additional data available on dry eye lens weight, or at least on the body weight and length of voles) is burdened with a certain degree of error. For instance it is known that in the very young class (up to 4 weeks old) all individuals are free of intestinal helminths, but this does not justify arriving at the simple conclusion that the number of uninvaded individuals is equal to the number of very young individuals, since uninvaded individuals also occur in the young class $(40 \%)$ and occasional cases occur even in the old class (about $2 \%$ ), cf. Table 3 . Therefore, when using parasitological indexes for assessing age structure, we must make a correction for the overestimated percentage of very young individuals in relation to the factual state, and this error will be far smaller if we consider uninfested individuals in general as very young and young combined. The case is analogical in groups of individuals infested by Syphacia obvelata only (young voles), by mixed invasion (adult voles) or only by Heligmosomum spp. (old voles). Each of these types of infestation is characteristic of a given age class and dominates in it, but also occurs in the other classes (cf. Table 3). 
The age of individuals in the study population and reproduction dynamics are not the only factors affecting the parasitocenosis structure in $M$. arvalis. Invasion by the nematode Syphacia obvelata spreads by means of contacts between individual hosts. The frequency of such contacts is connected not only with the mating period (as shown in the present study), but also with the social and spatial structure of the host population, and its density etc. An important role is also played by the habitat in which the given population lives $(\mathrm{Er} \mathrm{h}$ a r dova, 1958, $\mathrm{Prok}$ opi c, 1972). Further studies are, however, essential in order to obtain a better knowledge of these relations.

Parasitological indexes should therefore be used primarily to confirm and supplement descriptions of the age structure of vole populations, based on more accurate methods. When used independently such indexes may ke useful for comparative analysis either of two different host populations, or the same population at different times, but even so such comparison can be limited only to the descriptive form (more or fewer young or old individuals).

\section{REFERENCES}

1. Adamczewska-Andrzejewska K., 1973: The lens weight as on indicator of age in the wild Microtus arvalis population. Bull. Acad. pol. Sci., Cl. II, 21, 5:

2. E rhardová B., 1958: Parasitičti červi hlodavci Ceskoslovenska. Cs. Parasitol., 5, 1: 27-103.

3. Kisielewska K., 1971: Intestinal helminths as indicatores of the age structure of Microtus arvalis $\mathrm{Pall}$ a s, 1779 population. Bull. Acad. pol. Sci., Cl. II, 19, 4: $275-282$.

4. Martinet W., 1966: Determination de l'age chez la compagnol de champs (Microtus arvalis) par la pesce du cristalin. Mammalia, 30, 3: 425-430.

5. Petrusewicz K. \& Andrzejewski R., 1962: Natural history of a freeliving population of house mice. (Mus musculus L.) with particular reference to groupings within the population. Ekol. pol. A., 10, 5: 85-122.

6. Prokopič J., 1972: Biocenotical study on Cestodes of small mammals in various biotopes. Acta Sc. Nat. Brno, 6, 10:1-68.

Accepted, March 20, 1973.

Institute of Parasitology,

Polish Academy of Sciences,

Pasteura 3, 02-093 Warszawa, Poland. 


\section{Krystyna KISIELEWSKA i Zofia ZUBCZEWSKA}

\section{HELMINTY JELITOWE JAKO WSKAŹNIKI DYNAMIKI ROZWOJU POPULACJI ŻYWICIELA - POLNIKA ZWYCZAJNEGO}

\section{Streszczenie}

W okresie od IV 1970 do XI 1971 roku zbadano 612 osobników Microtus arvalis (P a llas, 1779) pochodzących z dwóch izolowanych populacji zasiedlających uprawę lucerny. Populacje te były pod stałą kontrolą ekologiczną i parazytologiczną.

Sekcje parazytologiczne wykazały w badanych populacjach nornika obecność pięciu gatunków helmintów jelitowych (Tabela 2), z których nicienie Syphacia obvelata oraz dwa gatunki z rodzaju Heligmosomum uznano za Kisielewską (1971), jako wskaźniki struktury wiekowej i dynamiki rozrodu populacji żywiciela. Rzeczywisty wiek norników uzyskano na podstawie ciężaru suchej masy soczewek óka, opracowanych przez Adamczewską-Andrzejewską (1973).

$\mathrm{Na}$ podstawie ilościowej i jakościowej struktury zarażenia (Ryc. 1) wyodrębniono następujące grupy norników: (a) niezarażone, (b) zarażone tylko nicieniem Syphacia obvelata, (c) zarażone jednocześnie $S$. obvelata i nicieniami z rodzaju Heligmosomum, (d) zarażone tylko Helighosomum spp. Każda $\mathrm{z}$ wymienionych grup jest charakterystyczna dla innej klasy wiekowej norników i w niej dominuje (Tabela 3). Ponadto stwierdzono, że średnia intensywność inwazji maleje wraz z wiekiem żywiciela dla $S$. obvelata, a wzrasta dla Heligmosomum spp. (Ryc. 2), oraz, że u starych osobników częściej spotyka się inwazje więcej niż jednogatunkowe (Tabela 4). Dla każdej z klas wiekowych obliczono sredni ciężar suchej masy soczewki oka oraz odchylenie standardowe (Ryc. 3) w celu ustalenia statystycznej różnicy między tymi klasami.

Prześledzono w kolejnych miesiącach badanego okresu zmienność intensywności inwazji helmintów wskaźnikowych (Ryc. 4) oraz procentowy udział nornikow różniących się typem zarażenia właściwym określonym klasom wiekowym (Ryc. 4). $\mathrm{Na}$ tej podstawie scharakteryzowano dynamikę rozrodu populacji nornika w dwóch kolejnych sezonach rozrodezych (1970 i 1971); w 1970 roku rozród był bardzo intensywny ( $\mathrm{z}$ wyraźnym szczytem $\mathrm{w}$ okresie od lipca do września). Procentowy udział młodych w populacji przewyższał w tym okresie pokolenie rodzicielskie, pasożytem dominującym w populacji nornika był $S$. obvelata. W 1971 roku przebieg rozrodu miał charakter bardziej jednostajny (bez wyraźnego szczytu), nieliczne przyrosty młodzieży nie dominowały nad starszą częścią populacji, dominantami spośród pasożytów były nicienie z rodzaju Heligmosomum. Wskaźniki parazytologiczne zestawiono $\mathrm{z}$ danymi dotyczącymi liczby osobników młodych, wchodzących do populacji (nieopublikowane dane Adamczewskiej-Andrzejewskiej \& Jurgi ela, Ryc. 4).

Dyskutowano wiarygodność i przydatność wskaźników parazytologicznych przy ocenie struktury wiekowej populacji żywiciela. 